\title{
NOT THE HONEY BEE (APIS MELLIFERA L.) QUEEN, BUT THE DRONE DETERMINES THE TERMINATION OF THE NUPTIAL FLIGHT AND THE ONSET OF OVIPOSITION - THE POLEMICS, ABNEGATIONS, CORRECTIONS AND SUPPLEMENTS
}

\author{
Jerzy Woyke \\ Division of Apiculture, University of Life Sciences (SGGW), 166 Nowoursynowska, \\ 02-787 Warsaw, Poland \\ *corresponding author: jerzy_woyke@sggw.pl \\ Received: 20 July 2016; accepted: 16 November 2016
}

\section{Abstract}

This paper emphasizes the topics concerning honey bee (Apis mellifera L.) mating biology, which have not been described in the recently published book of Koeniger et al. (2014). At the beginning of natural mating, the drone becomes paralyzed. However, the muscles in the abdomen continuously contract shrinking the abdomen till mating has ended and the pair have separated. It is not the queen that ends the nuptial flight. The termination of the nuptial flight is determined by the drone, which fails to remove the mating sign of the previous drone from the sting chamber of the queen. The mating sign originates from two or more drones. The queen also does not determine the age at which she starts oviposition. It is the last drone, which tried to mate, but failed to remove the mating sign of the predecessor, that determines the age that the queen starts oviposition. The book of Koeniger et al. ( 2014), together with this paper, present the current knowledge of the mating biology of honey bees.

Keywords: drones, mating of bees, multiple mating, oviposition, queen bee

\section{INTRODUCTION}

Historically, Woyke (1958b, 42 pp.) conducted the most detailed anatomical studies on the natural mating of queen bees. The shortened version was published by Woyke and Ruttner (1958). Woyke (1960, 91 pp.) also performed the most detailed investigation on natural and instrumental insemination. A total of 1300 queens were investigated and 3000 mating flight were observed. A study concerning 70 instrumentally inseminated queens was performed. The shortened version of this study was also published (Woyke, 1962). In 2014, Koeniger et al. published an important book on the mating biology of the honey bee (Apis mellifera L.). The book presents a review of the investigations concerning this topic. One of the reviewers of the book, Marla Spivak, wrote, "Bee sex is complex and beautiful, and fortunately, there are still mysteries for future researches to unravel". In fact, the mysteries have already been unraveled. Two remarkable papers (Woyke, 2010 and 2011) on this topic were neither cited nor interpreted in the book. The first of these two papers complements the knowledge regarding the honey bee's mating biology. The second paper presents two completely unexpected results, which were a surprise even to the author. The first surprising result was that it is not the queen but the drone that determines the termination of the nuptial flight. The second surprise was that the mating sign does not originate from one, but from two or more drones.

Omitting these two publications means that the readers of the book by Koeniger et al. are deprived of the recent groundbreaking research. They do not know the present up-to-date knowledge regarding the mating behavior of A. mellifera queen bee. This is a great shortcoming of this book. To make up for this deficiency, and to present the whole picture and current knowledge on this topic, I have written this paper. To stimulate further studies and creative discussion, I have also added my own, original interpretations or conclusions that may entice 
debatable.

The research literature (by other researchers) presented in the book by Koeniger et al. (2014) is not repeated in this paper. I have selected only those papers which were not cited, or which were required to understand or verify my text. To make it easy for the readers to follow the discussion, any texts cited from the book by Koeniger et al. (2014) are written in italics. The pages of the book on which the discussed topics are presented my be seen by clicking the link under the Koeniger et al. (2014) position, in the References chapter.

\section{REPRODUCTIVE ORGANS OF A DRONE}

The anatomy of the drone's reproductive organs is presented in Fig.1. It is necessary to know the structure of the cervix (Fig. 2) to understand the process of endophallus eversion and natural

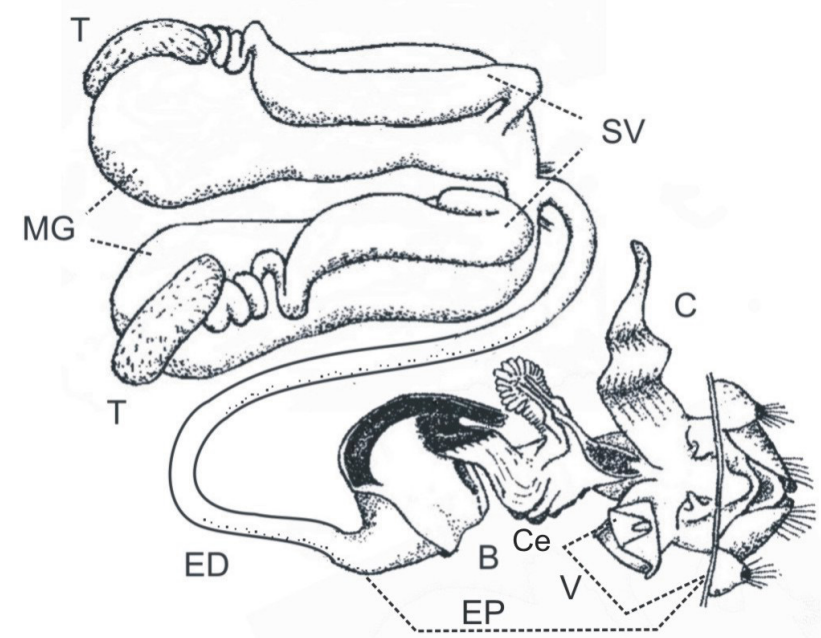

Fig. 1. Reproductive organs of a drone. B - bulb, C - cornua, Ce cervix ED - ejaculatory duct, EP - endophallus, MG - mucus glands, T - testes,

$\mathrm{V}$ - vestibulum (modified after Woyke 1958a and b)

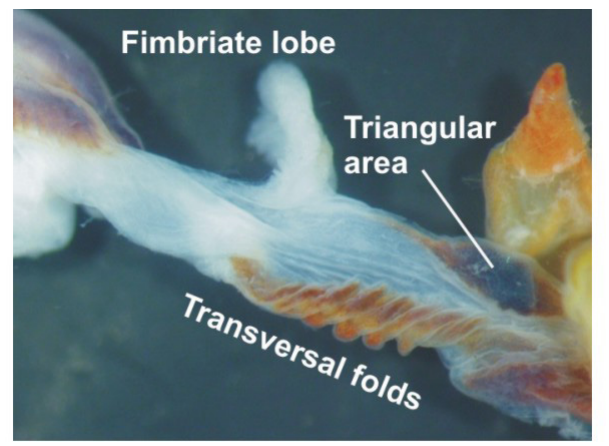

Fig. 2. The cervix. Inside the transversal folds is the cervical duct mating. The cervix is a laterally compressed part of the endophallus. Elongated fields (area) covered with hairs and spines are inside the lateral walls at the lower part the cervix. The hairs and spines keep both sidewalls together, like a hook-and-loop fastener. A cervical duct having a $0.3 \mathrm{~mm}$ diameter is present inside the ventral part of the cervix. It is embraced by several transversal folds.

\section{THE SEVEN STAGES IN THE PROCESS OF NATURAL MATING}

Seven characteristic mating stages (MS) may be determined during the process of natural mating. Woyke (1958a and b, Fig. 1, EP) published the most detailed drawing of the uneverted endophallus in the abdomen of the drone. At the beginning of the mating, the drone brings the end of his abdomen closer to the queen's open sting chamber. The drone's abdomen muscles contract and the endophallus is everted into it. During the first mating stage, the endophallus is only partly everted into the queen's sting chamber. The curved slender tip of the partly everted endophallus is inserted into the queen's vaginal orifice (Fig. 3, MS 1).

According to Koeniger et al. (2014, p.79), "The drone contracts his muscle layer of the abdomen in one sudden pulse. Almost all of his entire body fluid is pressed into his endophallus. The wall of the queen's sting chamber resists the pressure, so the drone everts the endophalIus only halfway by his own power. At the same time, the drone becomes paralyzed and cannot fly."

My investigation (Woyke, 1955) shows, that only the head and the thorax of the drone become paralyzed. The abdomen remains active. The abdominal muscles continue to contract during the whole mating process up to the separation of the pair.

At the beginning, the bulb inside the partly everted endophallus in the sting chamber of the queen is empty. Despite the drone's head and thorax being paralyzed, the muscles of the seminal vesicles (Fig. 1, SV) contract and push the semen into the ejaculatory duct (ED), 
Fig. 3. Mating stage (MS) 1. (Longitudinal section) The slender tip of partly everted endophallus is inserted into queen's vagina. No semen is in the tip. Orifiice of the cervix (OC) is tightly closed
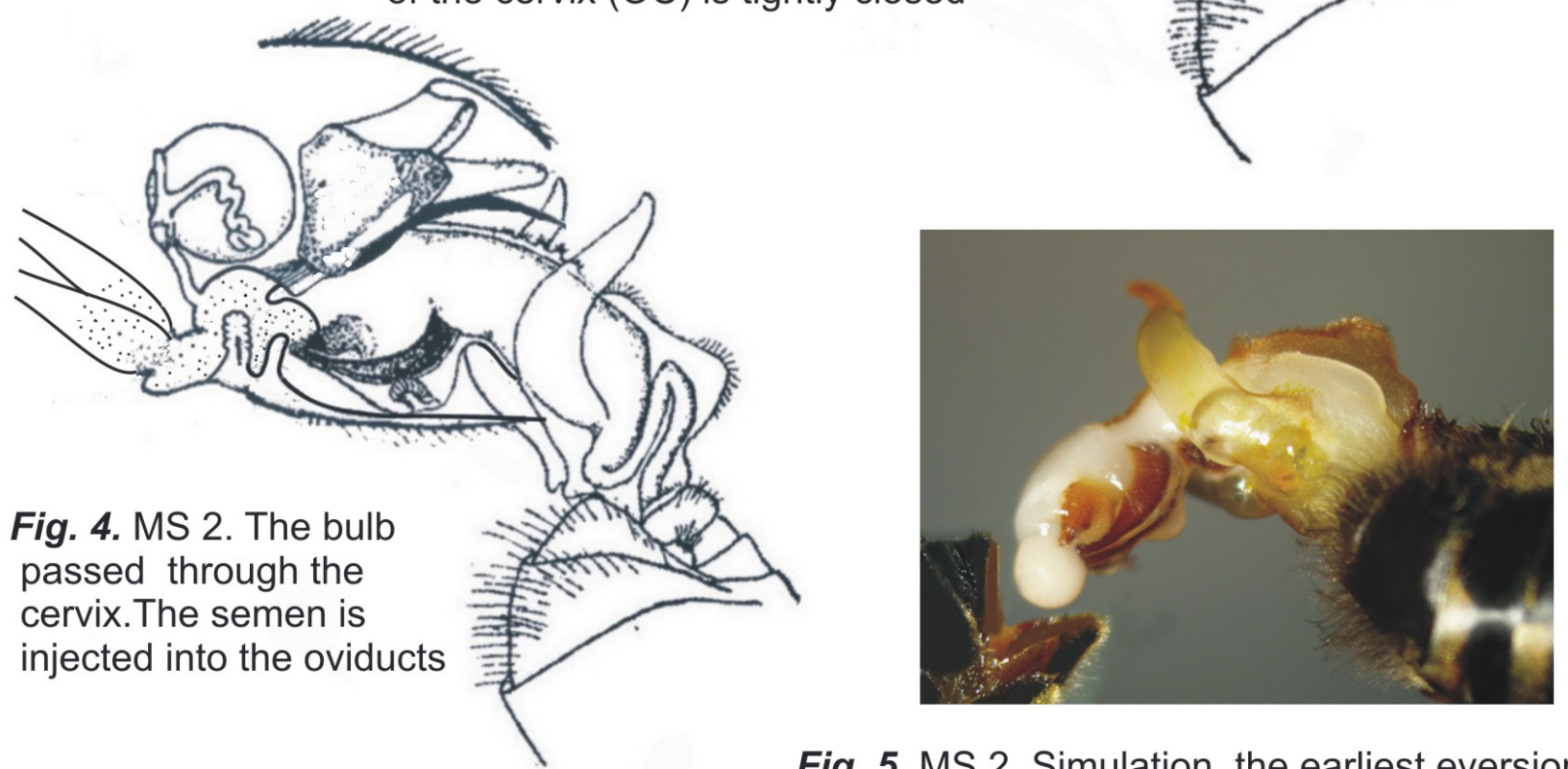

Fig. 5. MS 2. Simulation, the earliest eversion stage, the semen can be injected
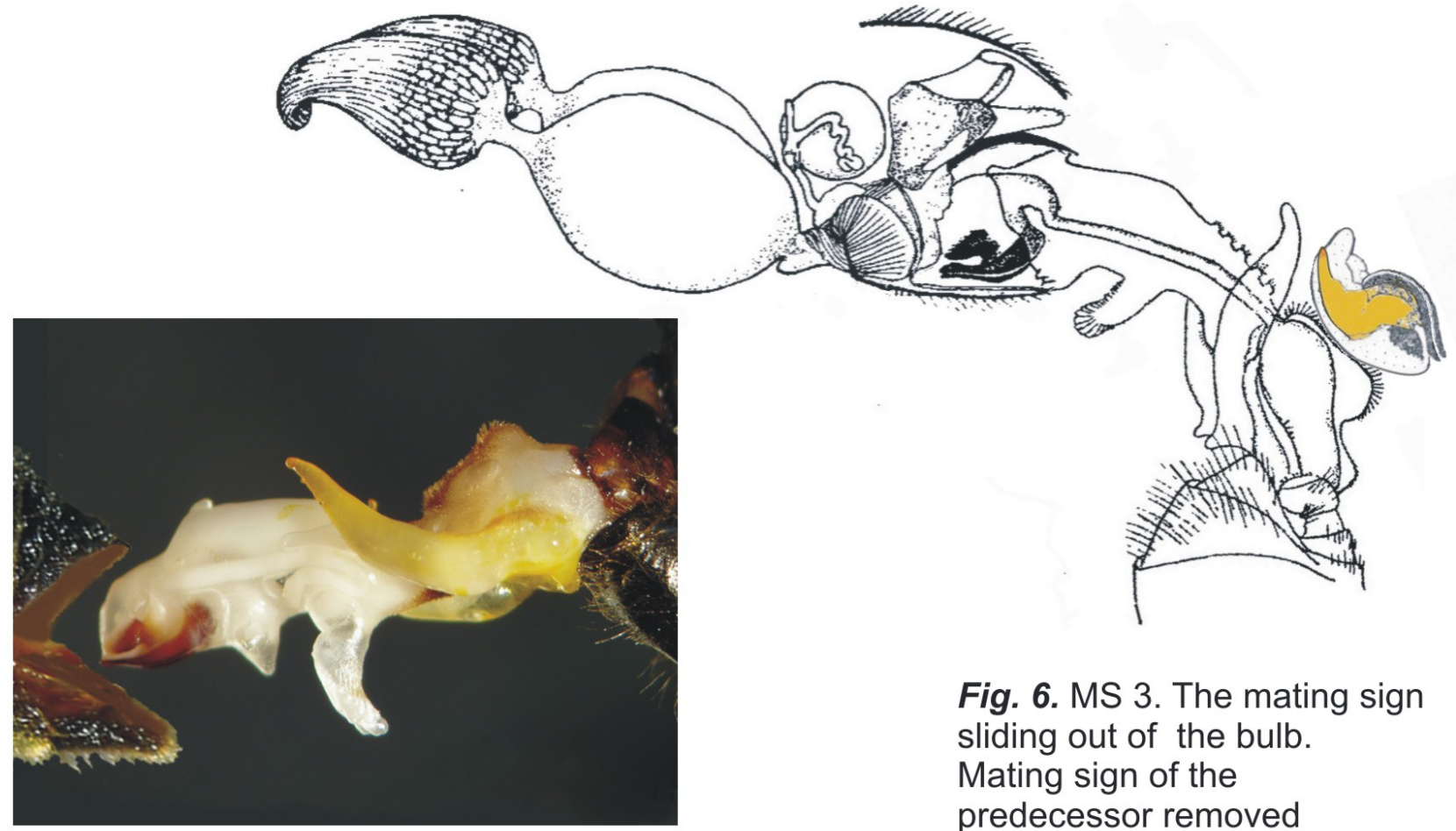

Fig. 6. MS 3. The mating sign sliding out of the bulb. Mating sign of the predecessor removed

Fig. 7. MS 3. Simulation, creating the mating sign 
(Woyke, 1958a and 1958b). Next, the muscles of the mucus glands (MG) contract and push the mucus into the ejaculatory duct. The mucus pushes the semen forward into the bulb (B), and it also fills the bulb (Fig. 3). The continuous muscle contractions of the mucus glands (Fig. 1, MG) tear off the glandular epithelium, which is also pushed into the ejaculatory duct. The epithelium pushes the mucus forward, and the epithelium also fills the posterior part of the bulb in the partly everted endophallus in queen sting chamber (Woyke, 1958a and 2010). No sperm is present in the thin tip (cervical thin tube), (Fig. 3, MS 1).

Koeniger (1984, p.198) writes " Die Cervix dringt mit ihren Qverlisten in die geóffnete Vagina ein" Koeniger et al. (2014) present on their Fig. 8.4, partly everted endophallus of a drone in the sting chamber of a queen. The sperm is passing from the bulb through the thin tip (cervix) into the common oviduct of a queen. [to see this, click the link under the Koeniger et al. 2014 position, in the Woyke References and open $\mathrm{p}$. 80 with Fig. 8.4].

The legend informs; " the thin tip (cervix) enters the median oviduct behind the vaginal valve and transfers the sperm". The text (p. 80) describes that "only sperm is found in the cervix while the mucus stays behind in the bulb".

According to Koeniger et al. (2014, p. 80), "The tip of the endophallus in this stage forms a thin tube (cervix) that is inserted behind the valve fold of the vagina. Only sperm is found in the cervix. The thin tip (cervix) enters the median oviduct behind the vaginal valve and transfers the sperm (Legend to Fig. 8.4)." [to see this, click the link under the Koeniger et al. 2014 position, in the Woyke References and open p. 80 with Fig. 8.4].

My investigation show, that the sperm never is present inside the cervix. Neither during natural mating (Woyke, 1958a, Figs 7, 8 and 9), nor during instrumental insemination (Woyke, 1958b, Figs 3 and 4).

Fig. 15a shows that inside the partly everted endophallus the almost whole uneverted cervix and the bulb with sperm and mucus are present. The cervix is empty.
Woyke (2008) found that the internal side walls of the cervix a provided with special strong hairs which keep the walls very tight together. Due to this structure, during eversion, the endophallus stops at the partly everted stage. A slender curved tip (thin tube) appears at the end of the cervix. No any opening is present in this tip. However, a line (fissure) is visible at the dorsal wall of the curved tip. The edges are tightly closed together. No any sperm can pass trough it, to be transferred into the common oviduct of a queen. Cross section trough partly everted endophallus shows that the bulb is filled with mucus and sperm. However, the cervix is empty (Woyke, 2008, Fig. 19).

During natural mating, the eversion of the endophallus stops for a while after the partial eversion. Higher pressure is required to reach the second mating stage. When the required pressure is reached, the large bulb filled with mucus and sperm is pushed by force through the cervix and the thin tip at the end of the cervix. Only after the bulb passes trough the cervix and the thin tip (tube), the tips of the longitudinal chitin plates and the orifice of the bulb appear at the end of the so far everted endophallus (Figs 4 and 15b), [MS 2]. Only now, the semen may come out of the bulb (Fig. 5). During natural mating the sperm is injected by force out of the bulb at the end of the endophallus, into the common oviduct of the queen.

At this eversion stage the sperm may be collected also for instrumental insemination. Any person who inseminates queens instrumentally knows well, that no sperm appears at the end of a partly everted endophallus and no sperm can be collected from the tip of partly everted endophallus.

After the sperm is injected into the oviducts, the third characteristic mating stage (MS 3) occurs. The chitin plates together with the mucus and the epithelium slide out of the endophallus, and the mating sign is created (Figs 6 and 7). The mating sign remains in the sting chamber of the queen. The endophallus becomes fully everted. However, it is still attached to the end of the mating sign (Fig. 8); presenting the fourth stage (MS 4) of the mating process. The pressure inside 


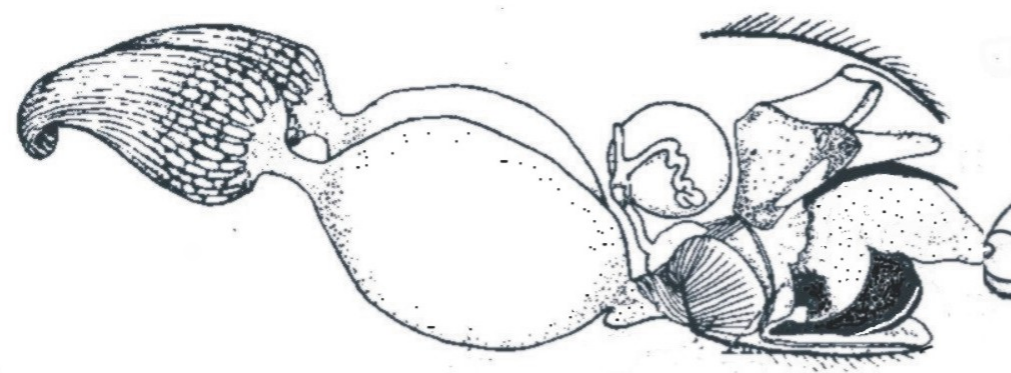

Fig. 8. MS 4. Mating sign without orange membranes created and the endophallus attached to its end

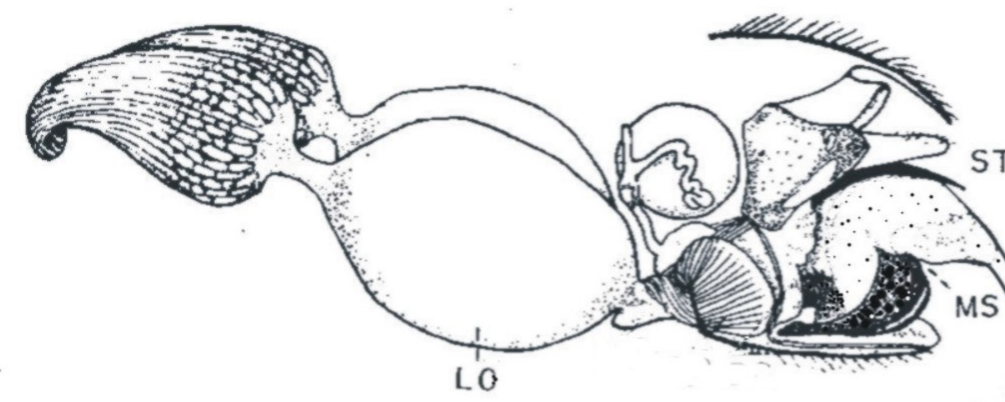

Fig. 9. MS 5. Mating sign with thin thread (TT) to which the endophallus is attached

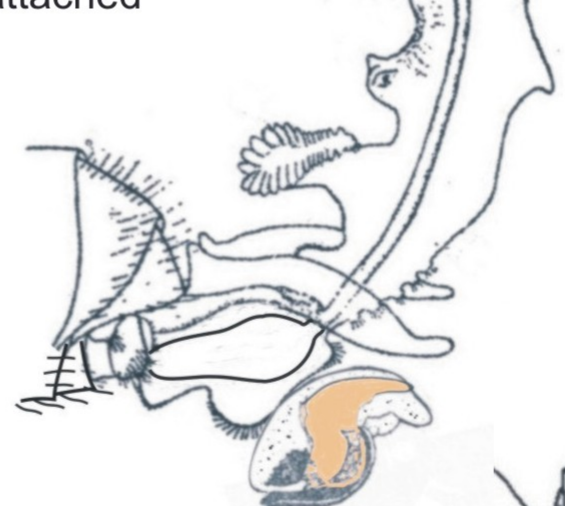

Fig. 10. MS 6. Mating sign with thin thread (TT) without orange membranes

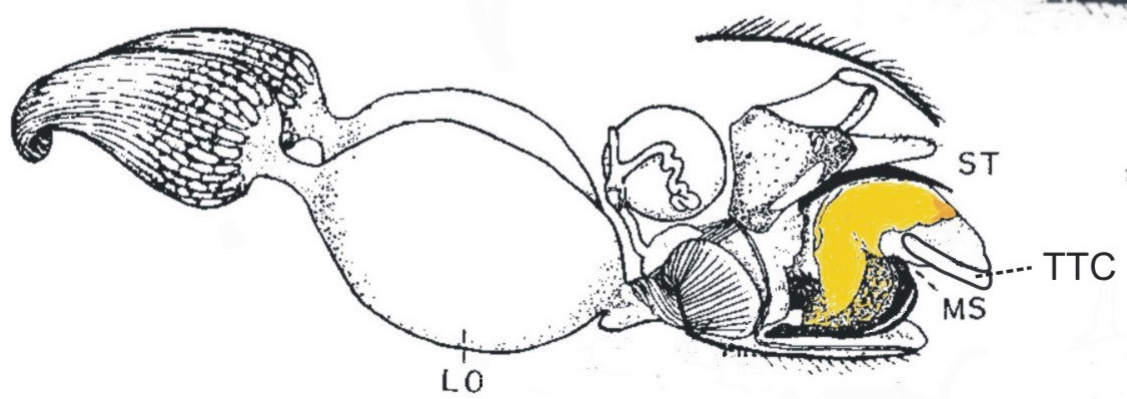

Fig. 11. MS 7. Mating sign covered with orange membranes. The thin thread curved (TTC) on the mating sign (MS) 
the endophallus is still so high that it squeezes the ejaculatory duct inside the endophallus. As a result, the epithelium, which was torn from the mucus glands, and now is present inside the ejaculatory duct, is pressed out of the endophallus (Fig. 9, TT). The epithelium appears as a whitish thread at the end of the mating sign. The endophallus is still hanging at the end of this thread (Fig. 9, MS 5).

The thread is not able to support the drone, and thus it breaks a short distance from the end of the mating sign (Fig. 10, MS 6). Some queens return to the hive with this thread. Other authors have also noticed that thread, but they believed this was the ejaculatory duct (Zander, 1921, p.73). The final stage is observed in most of the queens returning to the nest. The thin thread is curved and pushed forward onto the surface of the mating sign (Fig. 11, CTT; MS 7). Therefore, the end of the mating sign looks blunt. The reason for this phenomenon will be described later.

Koeniger et al. (2014, p. 81) write: "Because the drone is paralyzed, the queen takes an active role to separate quickly from the drone. She contracts her sting chamber. This initiates the full eversion of the endophallus. The sperm are transferred from the cervix into the oviducts." The authors do not explanation how a queen can stimulate the full eversion of a partly everted endophallus of a paralyzed drone, and transfer the sperm into the oviducts. The endophallus has neither nerves nor muscles. Also during full eversion, the mucus glands and the seminal vesicles are pushed out of the abdomen into the vestibulum of the endophallus (Figs 6, 8, and 9). It is impossible to imagine how the contraction of a queen's sting chamber could initiate full eversion of the endophallus, and push the glands and the vesicles out of the abdomen.

In fact, no active role needs to be played by the queen, nor is it possible. The contraction of a queen's sting chamber is not able to initiate full eversion of a partly everted endophallus. When a drone is manually provoked for partial eversion of the endophallus, no external manipulation will stimulate full eversion of it. Only the pressure of the abdomen will result in full eversion of the partly everted endophallus.

The photos in the poster of Koeniger (poster, no date, Fig. 14), show that after the head and the thorax of the drone become paralysed, his abdomen shrinks to about half the original size (Fig. 14, second drone). Next, the abdomen continues to shrink till the end of the mating process, at which time the abdomen is about one-fourth of its original size (Fig. 14, third drone). It is not necessary or possible for the queen to play an active role in inducing the full eversion of the endophallus to finish the mating process.

There is the question of whether it is possible that body parts are active after an animal dies. Such a phenomenon does not occur in several animal species, but it does occur in insects. The nervous centers are not only located in the brain. They are also located also in the segmental nervous ganglions. When an insect is decapitated, it still can move and even fly. After a worker bee stings somebody, the sting is left in the skin of the person's body. However, the muscles of the sting left in the skin are active. The parts of the sting are moving and the sting penetrates the skin, although the bee is absent. A similar phenomenon occurs during natural mating after the drone's head and thorax become paralysed. The abdominal muscles are continuously contracting, which assures the progress of the mating process.

\section{REMOVED MATING SIGN ORIGINATES FROM TWO DRONES}

Sequential mating occurs when the mating sign from the previous drone is inside the queen's sting chamber. Despite the chamber being filled, it is easy to open the last abdominal sclerite. The partly everted endophallus of the next drone can be introduced between the sclerite and the mating sign (Woyke, 2011, Fig. 22). The cornua of the next drone embrace the mating sign of the previous drone. The cornua may serve as parameres (genital claspers) in other insects, fixing the pair in copula and directing the slender tip of the endophallus into the queen's vagina. Woyke (1955) described the mechanism of the 


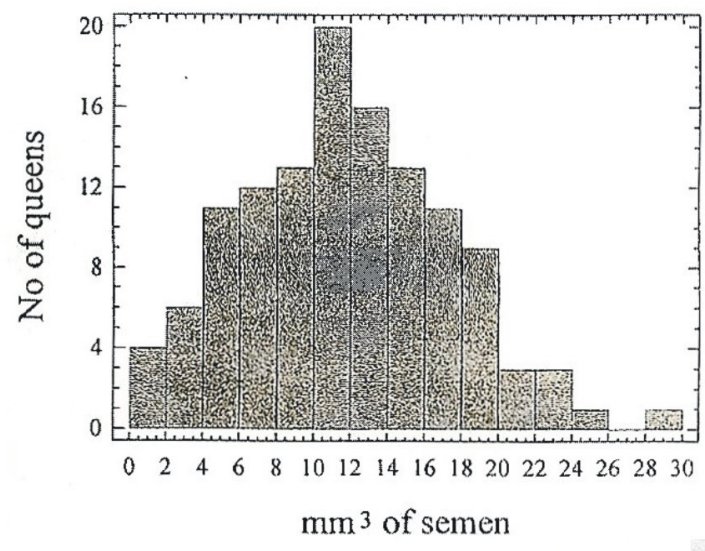

Fig. 12. Volume of semen in oviducts of 123 queens returning from nuptial flight (Woyke 1960)

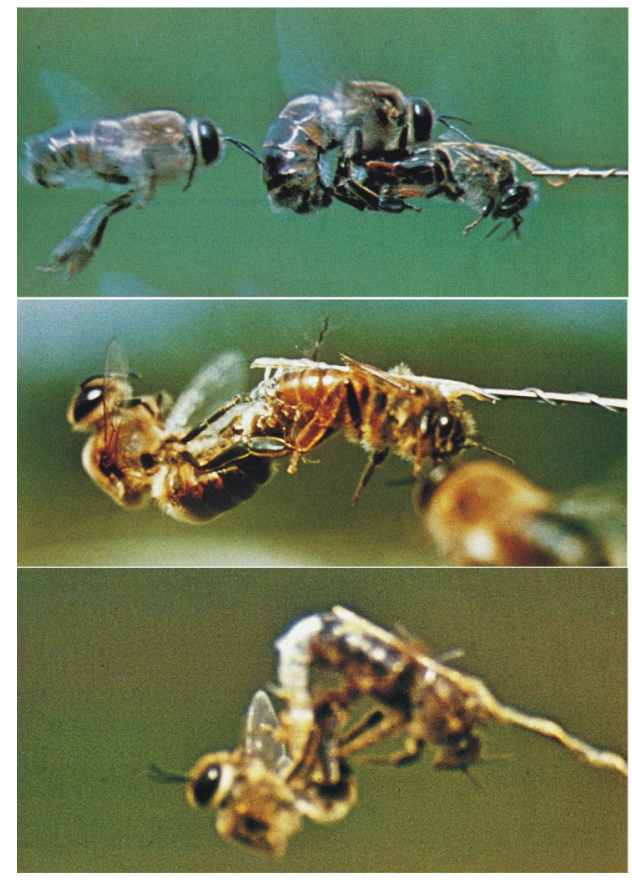

Fig. 14. Three stages of natural mating (G. Koeniger)

movement of the cornua. The cornua bend down because the orange sticky membranes bursts at the dorsal wall of the cornua and the membranes slides down toward the ventral wall of the cornua. The orange sticky membranes stick to both sides of the mating sign of the previous drone inside the sting chamber of the queen (Woyke, 2011 Fig. 22). Progressive eversion of the endophallus results in a pulling

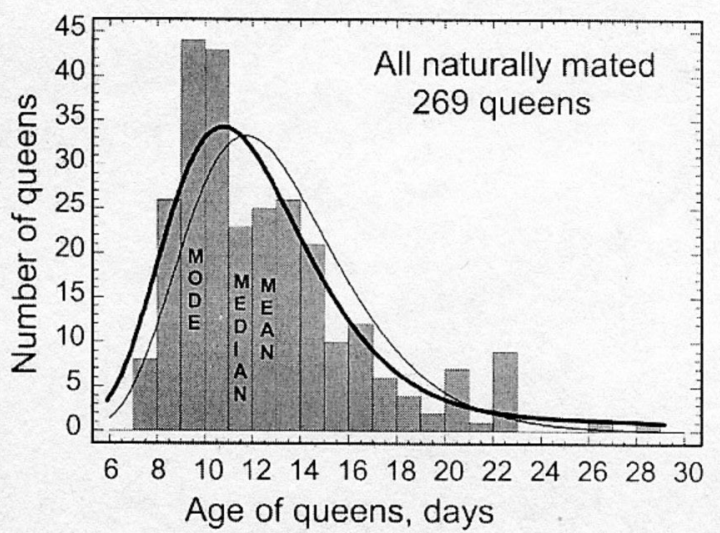

Fig. 13. Lognormal distribution of the age at which naturally mated queens initiated oviposition. The thin line represents curve, in which its mean is equal to the mean of the data. In the bold curve, the mean was replaced by the median of the data (Woyke 2011)

of the mating sign of the previous drone out of the queen's sting chamber. The sign becomes attached to the basal, hairy, vestibulum field of the endophallus of the next mating drone (Figs 6, 8, and 9). Thus, the removed mating sign originates from two drones. The chitin plates and the mucus originate from the previous drone, but the orange membranes from the next mating drone, which removed that sign (Figs 6, 8, and 9).

Theoretically, it may happen that one of the following drones trying to mate with the queen removes the mating sign that had not been removed by the last unfortunate drone. In this case, the removed mating sign would originate from three drones - the mucus and the chitin plates from one drone, the orange cornua membranes from the unsuccessful next drone, and the next pair of orange membranes from the successful, third drone. Unfortunately, I have no evidence to show for such a phenomenon.

\section{THE MATING SIGN IN THE QUEEN'S STING CHAMBER ORIGINATES FROM TWO OR MORE DRONES}

The mating sign left in the queen's sting chamber by the last drone is not covered by orange membranes (Figs 8, 9, and 10). The cornua of the endophallus of the drone, which 


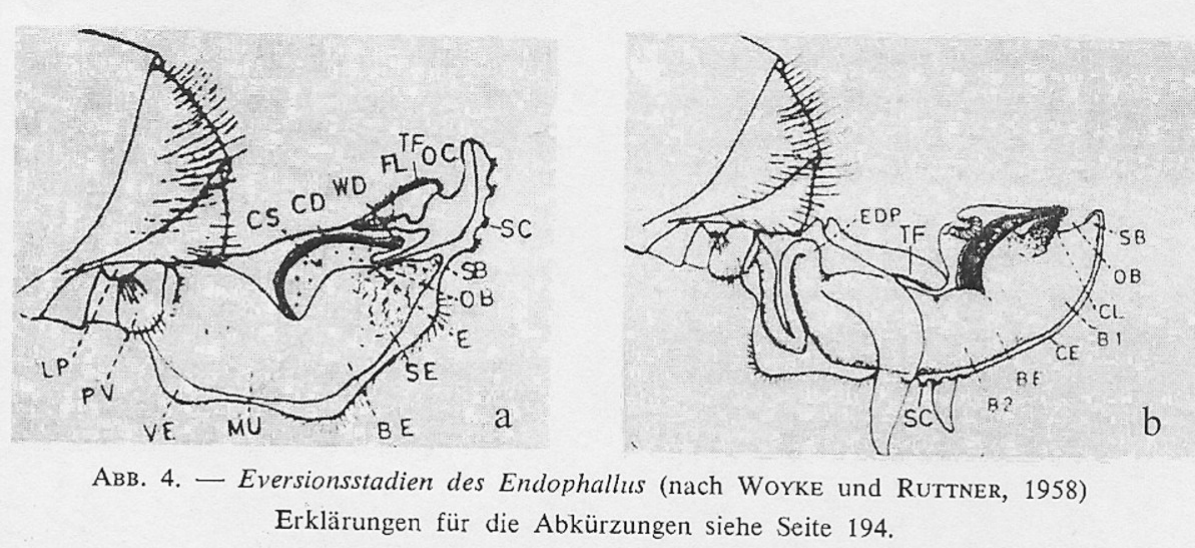

FIG. 4. - Stages in the eversion of the endophallus (after WOYKE and RUTTNER, 1958) Key to abbreviations see page 194.

Fig. 15. a - section through partly everted endophallus, b - next stage of eversion in which the semen is coming out of the bulb (Koeniger 1984 after Woyke and Ruttner 1958)

recently mated with the queen, are also without those orange membranes. Instead, the orange membranes remain on the removed mating sign.

In any subsequent matings, the unfortunate drone mates with the queen and his cornua embrace the mating sign of the predecessor. The orange membranes of the cornua become stuck to the mating sign of the predecessor (Fig. 11). However, the unfortunate drone fails to remove the mating sign of the predecessor. This means that the mating sign in the sting chamber of the queen returning to the colony, originates from two drones. The chitin plates, the mucus, and the epithelium originate from one drone, but the orange membranes covering the mating sign are from the second drone, which failed to remove the predecessor's sign. Some queens return to the colony with two pairs of orange membranes. There are also queens, which return with an additional incomplete mating sign (Woyke, 2011, mating sign without chitin plates). This phenomenon indicates that after the drone failed to remove the predecessor's mating sign, the next drone/s, which tried to mate with the queen, also failed to remove the mating sign. The above description shows that the mating sign in the sting chamber of a queen returning to the colony, originates from two or more drones (Woyke, 2011).

It is impossible that the corneal orange membranes of the successfully mated drone become stuck to the chitin plates of the same drone. During semen collection for instrumental insemination, it sometimes happens that the orange membranes of the cornua stick to the fingers. However, it never happens that the orange membranes stick to the chitin plates of the endophallus.

Koeniger et al. (2014) present on p. 98, in Fig.10.1b, a queen with the mating sign covered by the orange membrane (J. Woyke's authorship not noted). The authors do not explain from where or how the membrane appeared on the mating sign. They also do not state whether the sign originates from one or two drones.

In the book by Koeniger et al. (2014), the mating sign on p. 83 in Fig. 8.7, originates from 3 drones, though the authors did not mention this.

Lack of information of the origin of the mating sign from three drones concerns reproduction of the same sign by Gorshkov et al. (2015, Fig. 1).

The chitin plates and the mucus originate from one drone, the light orange membranes from the second younger drone, and the dark orange membranes from the third older drone.

Unfortunately, I could not use molecular genotyping as verification because neither the orange membranes nor the mucus contain even parts of epithelial cells (Woyke, 2010). Thus, they do not contain the DNA. 


\section{NATURALLY AND ARTIFICIALLY PROVOKED EVERSION OF THE ENDOPHALLUS}

The materials available show that eversion of the endophallus during natural mating, and provoked eversion to collect semen for instrumental insemination, is similar.

The difference is that during provoked eversion, the chitin plates do not slide out of the endophallus, because the backpressure of the queen's sting chamber is missing. However, when the free eversion is artificially hindered, the chitin plates also slide out (Fig. 7). Of course, during natural mating, the semen is injected into the queen's oviducts, while during provoked full eversion semen and mucus disperse on different parts of the fully everted endophallus.

\section{CAUSES OF REPEATED MATING FLIGHTS}

Some queens mate during one mating flight only, and do not fly out of the nest again. Other queens mate during two, three or even four nuptial flights (Roberts, 1944; Alber et al.,1955). Why do already-mated queens fly out of the nest? Which of the queens mate again? These are important and interesting questions. Since this topic is not described by Koeniger et al. (2014), it is described at length here.

To answer the question of why mated queens fly out of the nest, Woyke (1960, 1962, and 1964) observed 2434 flights of 628 queens. A removable queen excluder was placed at the entrance to the hive. This excluder made it possible to control the mating flights of the queens. The previously mated queens, which returned with the next mating sign, were killed and examined. Those queens already had spermatozoa in the spermatheca from the previous, successful nuptial flight. However, the semen from the subsequent mating was still in the oviducts.

The results showed that $37 \%$ of the alreadymated queens did not fly out of the colony again, but $63 \%$ did fly out again. Not all 63\% of these queens mated again. Of the alreadymated queens, only $38 \%$ mated for a second time, and only $8 \%$ of the already-mated queens mated for a third time.

The spermatozoa in the spermatheca of 127 queens were counted. The queens which did not leave the nest again, had from the first nuptial flight [(N) Mean \pm s. e.] (49) $5.248 \pm$ 0.16 million spermatozoa in their spermatheca. Those queens, which flew out again, but did not mate for the second time, had (26) $4.628 \pm 0.22$ million spermatozoa in their spermatheca, and those, which mated for the second time, had (25) $3.462 \pm 0.30$ million spermatozoa from the first nuptial flight. Queens, which mated during a second and third flight, had (23) $5.979 \pm 0.22$ and (4) $6.975 \pm 0.50$ million spermatozoa in their spermatheca, respectively. It is obvious that the number of spermatozoa in the spermatheca from the previous mating was correlated with the future mating behaviour of the queens.

The data above show that the amount of semen in the oviducts resulting in 5.3 million spermatozoa in the spermatheca is sufficient to stop further mating flights of the queens. The amount of semen, which results in 3.5 million, does not prevent further flights and matings. Probably the number of spermatozoa in the spermatheca does not directly influence the mating behaviour of the queens. Herrmann (1969) found that as early as $12 \mathrm{~h}$ after mating, the neurosecretory cells in the brain and the endocrine organs of the queen undergo significant changes that result in a fundamental modification of a young mated queen's physiology and behaviour. It is possible that after the first mating, different extensions of the oviducts filled with various amounts of semen, influence the physiology and behaviour of the queen. When an already-mated queen flies out of the nest, her behaviour and attraction to the drones may differ from those of the unmated queens. The conclusion presented above (Woyke, 1964) was fully confirmed 41 years later by Schlüns et al. (2005) who wrote "we suggest, that queens adjust their nuptial flight frequencies according to the mating success of their previous nuptial flights."

The citation of Koeniger et al. $(2014$, p.115) is incomprehensible. The data generated by $G$. and $N$. Koeniger disprove the common view 
(J. Woyke, 1964) that the young queen continuously monitors the amount of semen she receives and uses this information to return to the colony. In fact, Woyke (1964) wrote about the queen's repeated mating flights out of the colony and not about their return to the colony, and this has been his point of view for 57 years (Woyke \& Ruttner, 1958, p.16).

It is still necessary to answer the question about why the queens do not collect a sufficient amount of semen during the first nuptial flight.

\section{WHY IS THE NUPTIAL FLIGHT TERMINATED? IT IS NOT THE QUEEN, BUT IT IS THE DRONE THAT DETERMINES THE TERMINATION OF THE NUPTIAL FLIGHT}

Alber et al. (1955) reported, that many queens mate even on their $3^{\text {rd }}$ or $4^{\text {th }}$ nuptial flights. Why is it that queens do not mate in one nuptial flight only? Why do some queens mate during the $3^{\text {rd }}$ or even the $4^{\text {th }}$ flight? Something has to force them to do this.

It was first noted by Roberts (1944), that queens mate not with one, but with several drones - during a single nuptial flight. According to Triasko (1951), the amount of semen in both oviducts originates from 4-5 drones. Taber (1954) estimated that queens mate with 4-9 drones. Woyke (1955) found $6-20 \mathrm{~mm}^{3}$ of semen in both oviducts and Woyke (1956) also reported $1.13-22.39 \mathrm{~mm}^{3}$ of semen in the oviducts of 20 queens. This shows an extraordinary variation in mating frequency from 1 to more than 15 drones during a single nuptial flight. Why do some queens mate with a highly varying number of drones, in similar environmental conditions? Why do some queens mate with only a few drones during one flight? Something prevents them from mating with more drones during a single nuptial flight.

As was described above, Woyke (1964) found that queens with 3.5 million spermatozoa in the spermatheca after a single nuptial flight fly out again and mate during a second flight. Whereas queens with 5.2 million spermatozoa in the spermatheca, do not fly out of the colony. So, the reason queens fly out for another mating is obvious: there was not enough semen collected previously. There is still the question of why some queens do not mate with more drones. It seems the queens could then collect a sufficient amount of semen and not need to repeat the nuptial flights. However, something prevents them from mating with more drones.

Koeniger et al. (2014, p. 110) argue that queens monitor their own mating success (Koeniger and Koeniger, 2007). "As short as possible, as long as necessary"; the queens return to the colony as soon as they have met a sufficient number of drones (2007, p. 606). Queens return to the hive after meeting the threshold for mating success (p. 609).

However, Woyke $(1960,1962)$ found 0.6 to 28.2 $\mathrm{mm}^{3}$, mean $=11.6 \mathrm{~mm}^{3}$ of semen in the oviducts of 123 queens (Fig. 12). The distribution of the semen volume was normal. This means that queens do not have a threshold for a certain amount of semen in the oviducts or for a certain number of matings that would enable the nuptial flight to be terminated.

Tarpy and Page (2000) investigated the mating behaviour of 32 queens. They concluded that queens do not have behavioral control over the mating number. According to them, "There is extreme variation in the number of matings on a single flight (0-13),..., the source of which is unclear". Tharpy and Page (2000) do not suggest what determines the number of mating and the termination of the nuptial flight. Why do some queens cease the flight after mating with only 1 drone and other queens' cease after mating 13 times? There must be a reason for such behaviour.

What can terminate the nuptial flight?

Queens and drones mate in the air during the mating flight. The duration of the mating flights varies between 15-30 minutes. The proper mating occurs during the short part of the mating flight, namely during the nuptial flight. The time starting from the grasping of the queen until the pair separates takes less than 2 seconds (Koeniger et al., 2014, p. 86). Thus, mating with 1,8 , or 15 drones would take 2, 16, and 30 seconds. Mating with several drones, one after another, lasts less than 1 minute. The duration 


\section{ง. APIC. SCl. VOL. 60 NO. 2.2016}

of all the matings in a single nuptial flight is so short that the queens cannot determine the termination of the nuptial flight.

Alber et al. (1955, p. 12) described two queens, which returned three times with the mating sign in the same day. One of the queens mated again the next day during two nuptial flights. Woyke (1960, p. 237, 1962, p. 24) found that out of 16 mated queens, 11 (69\%) mated again, the same day. Worker bees in the colony removed the mating signs. Some queens removed the sign themselves by rubbing the end of the abdomen through the edges of the comb cells. After resting for a time, the queens flew out for the next nuptial flight 19 minutes to 2 hours later, with the average being 52 minutes later.

A hypothesis can be formed from the results of both the publications: that mating with more drones during a single flight is hindered because of the impossibility of removing the mating sign of the last successful drone from the sting chamber of the queens. The next drone, which tried to mate with the queen failed to remove the sign of the predecessor. After removal of the mating sign in the colony, the queens fly out and mate again the same day or the other day. This hypothesis is supported by the following facts:

I described above that after the queen mates with one drone, a thin whitish thread is hanging at the end of the mating sign (Fig. 10, TT). However, in almost all queens returning to the colony, the thread is bent forward on the mating sign, making the mating sign look blunt (Fig. 11). Why does this happen? As was described above, the next drone mating with the queen pushes and bends the thin thread forward at the end of the mating sign of the predecessor. When an unsuccessful drone fails to remove the mating sign of his predecessor, the queen returns to the colony with a blunt mating sign. The impossibility of removing the mating sign from queen's sting chamber determines the cessation of the nuptial flight. Thus, the nuptial flight is terminated because the last drone trying to mate with the queen is not able to remove his predecessor's mating sign from the sting chamber of the queen.
After the drone completes the mating process, his orange cornua membranes become stuck to the removed mating sign of the predecessor (Fig. 8). The mating sign left by the drone in the sting chamber, is deprived of the orange membranes (Figs 8, 9, and 10). It is important to note, that all successively mated queens return to the colony with the mating sign covered by the orange membranes. This indicates that a drone tried to mate with the queen. His cornua had embraced the mating sign of the predecessor. The orange membranes stuck to the mating sign, but the drone failed to remove the mating sign of the predecessor. Thus, this failure to remove the mating sign of the predecessor is the reason that the nuptial flight has to be terminated.

It can happen that the orange membranes covering the mating sign are not clearly visible, see fig. 11. Instead they are covered by mucus, and some semen may be found somewhere on the surface of the sign. Both the elements originate from the next drone, which failed to remove the mating sign.

There are queens with mating signs covered by more than two membranes. There are also queens with two mating signs. These occurrences indicate that after a failed mating, another drone or other drones tried to mate but they also failed to remove the mating sign. Since subsequent matings were impossible, the queens returned to the colony.

Woyke (2011, his Fig. 3) observed a queen whose thin thread was not bent on the mating sign. The orange membranes covered the sign. This probably happened because the mating sign with the thin thread was located in the sting chamber not along the longitudinal axis of the queen but at an angle to it. The unsuccessful drone did not bend the thin thread. There are probably still other reasons that queens return from nuptial flights with an unbent thread.

The whole above explanation shows that the nuptial flight terminates because a drone fails to remove the mating sign. Other drones, which tried to mate with the queen, also failed to remove the sign.

The reason for the termination of the nuptial 
flight was previously hypothesized 57 years ago by Woyke (1958, p. 33) and by Woyke and Ruttner (1958, p. 16). At that time, though, the authors did not have sufficient supporting data.

Now we know from Woyke's paper (2011), that some drones leave the mating sign in the sting chamber of the queen, which the subsequent mating drone fails to remove.

There are varying degrees of difficulty needed to dislodge the mating sign from queen's sting chamber. Also, the ability to remove the sign is not perfectly developed in all drones.

According to Taber and Wendel (1958), the usual number of drones that mate with a queen is between seven and ten. This would suggest that, on average, every seventh to tenth drone fails to remove the mating sign of its predecessor.

The behaviour of different queens, and the anatomy of the sting chamber, probably also vary. The behaviour of that queen which mated three times on one day and two times more the next day (Alber et al., 1955), support the view that the removal of the mating sign from some queens is more difficult than from others.

The above information show that the queen feels the quantity of semen she collects in her oviducts during the nuptial flight. She recognizes when she did not gathered sufficient quantities of semen. She then wants to mate with more drones. However, the inability to remove the mating sign from her sting chamber by the unsuccessful drone prevents her from mating with more drones. Thus, the queen must terminate the nuptial flight and return to the colony. After removing the mating sign in the colony, the queen flies out of the colony, for the next nuptial flight on the same day or another day to supplement the amount of semen.

There is still a lack of knowledge on this topic. It may happen that a next successful drone removed a mating sign, which was not removed by one or more drones previous ones. If this happens, further mating occurs until the last drone fails to remove the sign.

\section{ONSET OF OVIPOSITION BY NATURALLY MATED QUEENS HAS A LOGNORMAL DISTRI- BUTION}

Extensive studies on this topic were conducted (Woyke et al., 2008b). The onset of oviposition (OofO) in 269 mated queens was checked in three localities: Warsaw, Szczecin, and Olsztyn. The studies took place in different environmental conditions in Poland. In Olsztyn, the temperatures were lower and rainfall occurred more often. The queens were introduced into small nuclei. Once the queens reached the age of 6 days, the presence of eggs and larvae in the combs was checked daily for the next 24 days, until the queens were 29 days old.

In all three locations, the earliest OofO by queens occurred when the queens were eight days old. The latest OofO differed in different places; from the age of 17 days in Warsaw to 29 days in Olsztyn. The mean age of the Oof0 varied in the three places; from 11.7 days old (Warsaw and Szczecin) to 15.3 (Olsztyn) days old. This shows that meteorological conditions influenced the OofO.

The overall median OofO occurred 1.1 days earlier and the overall mode 3.1 days earlier than the mean (13.1 days). The calculations showed that distribution of the OofO was not normal, but was skewed. The investigation revealed that of 22 types of distribution, the lognormal distribution best fitted the distribution of the queens' OofO (Fig. 13).

The study showed that using the mean value to present the results of the investigation on the OofO is misleading. The mean is influenced by the duration of the observation. When the OofO is conducted longer - the mean is higher. The results should be presented by the median or mode values because these values are not influenced by the duration of the observations.

It can be assumed that queens, which did not fly again after the first successful mating flight, had collected a sufficient amount of semen, and started oviposition first. Other queens had to fly out and mate again. Depending upon meteorological conditions, the length of time between successive mating flights may vary, and consequently, the time of the OofO may be different. 
Table 1

Percent progeny (per 1 drone) of queens inseminated with semen from 9 drones. Of the drones, the $1^{\text {st }}$, middle $5^{\text {th }}$ and the last $9^{\text {th }}$ were genetically marked (Woyke, 1963)

\begin{tabular}{|c|c|c|c|c|c|c|c|c|}
\hline \multirow{4}{*}{$\begin{array}{c}\text { Successive } \\
\text { drones }\end{array}$} & \multicolumn{8}{|c|}{ Queen No } \\
\hline & 426 & 427 & 428 & 446 & 459 & 460 & \multirow{3}{*}{ Mean } & \multirow{3}{*}{$\begin{array}{l}\text { CV } \\
(\%)\end{array}$} \\
\hline & \multicolumn{3}{|c|}{ Number of seasons (s) } & \multicolumn{3}{|c|}{ Number of combs (c) } & & \\
\hline & $1 s, 3 c$ & $1 \mathrm{~s}, 2 \mathrm{c}$ & $2 s, 6 c$ & $2 s, 6 c$ & $2 s, 5 c$ & $2 s, 5 c$ & & \\
\hline 1 & 17.8 & 10.8 & 14.0 & 14.0 & 23.2 & 12.0 & $15.30 b^{\star}$ & 29.7 \\
\hline $2-4$ & 13.4 & 9.6 & 9.4 & 10.3 & 9.7 & 9.6 & $10.33 a b$ & 14.8 \\
\hline 5 & 11.1 & 6.8 & 9.4 & 14.2 & 5.1 & 10.1 & 9.45 a & 34.0 \\
\hline $6-8$ & 13.4 & 9.6 & 9.4 & 10.3 & 9.7 & 9.6 & $10.33 a b$ & 14.8 \\
\hline 9 & 4.1 & 25.2 & 20.1 & 9.8 & 13.7 & 20.1 & $15.50 \mathrm{~b}$ & 50.1 \\
\hline CV (\%) & 42.0 & 58.9 & 37.8 & 18.6 & 55.6 & 36.5 & 24.30 & \\
\hline
\end{tabular}

Different letters after means indicate significant difference. ANOVA $F_{4,25}=2.73, p=0.05$

\section{THE DRONE, NOT THE QUEEN, DETERMINES THE AGE AT WHICH THE QUEEN STARTS OVI- POSITION}

That drone which fails to remove the mating sign of its predecessor during the nuptial flight determines the age at which the queens start oviposition. If the drone is the $15^{\text {th }}$ to $20^{\text {th }}$ to mate, it means the queen will collect a lot of semen during the first nuptial flight. Such a queen starts oviposition 2 days later, at the age of 8 days (Woyke et al. 2008). However, it may happen that already the second or the third drone fails to remove the sign of the predecessor. Such queen will collect less semen. She will conduct more nuptial flights and will start oviposition later (mean; 13 days). If a queen must wait several days due to meteorological conditions, she will initiate oviposition at an older age; up to 29 days old. Thus, it is not the queen, but that drone which failed to remove the mating sign of the predecessor, that determines the age of the OofO (Woyke et al. 2008).
CONTRIBUTION OF SUCCESSIVE DRONES TO THE INSEMINATION OF A QUEEN

Woyke (1963) instrumentally inseminated 6 queens with $9 \mathrm{~mm}^{3}$ of semen collected successively from 9 drones. Each of the 9 drones contributed $1 \mathrm{~mm}^{3}$ of semen. The $1^{\text {st }}$, the $5^{\text {th }}$, and the $9^{\text {th }}$ drones were genetically marked with colour mutants. After the queens started oviposition, the colour of the workers was classified. The worker bees were collected in one or two seasons. Altogether, the progeny from 27 brood combs was collected. A total of 39034 worker bees were examined (Tab. 1).

The ANOVA showed that the order of semen, which was inseminated, almost significantly ( $p=0.0515$ ) influenced the percentage of the offspring. The percentage of the middle drone (5) was found to be significantly lower (9.45\%) than that of the first and the last drones (15.3\%, 15.5\%, respectively). Nonetheless, the percentage of the offspring was not found to be significantly lower than the percentage of the offspring from drones 2-4 and 6-8. The coefficient of variation was very high. The variation in the distribution of progeny from successive drones varied from $14.8 \%$ to $50.1 \%$ for all 6 
queens and from $18.3 \%$ to $58.9 \%$ for particular queens.

In Koeniger et al. (2014, Fig. 10.5) the percentage of offspring from the middle drone (4) is also lower than that from the $2^{\text {nd }}$ and from the $7^{\text {th }}$ and $8^{\text {th }}$ drone.

Similar results had been obtained by Moritz (1986) 23 years after Woyke's (1963) report, and by Franck et al. (2002) 39 years later.

\section{CONCLUSIONS}

The most important FACTS not described in the book by Koeniger et al. (2014) are as follows:

1. Seven characteristic stages occurring during natural mating of Apis mellifera may be determined.

2. During natural mating of honey bees, only the head and the thorax of the drone become paralyzed. The muscles in the abdomen remain active till the end of the mating process.

3. The queen is unable to stimulate further eversion of a drone's partly everted endophallus after it is introduced into her sting chamber.

4. The mating sign of the predecessor removed during the mating process, originates from two drones.

5. The mating sign in the sting chamber of the queen returning to the colony, originates from two or more drones.

6. During the nuptial flight, a drone, which fails to remove the mating sign of his predecessor from the sting chamber of a queen, determines the termination of the flight, and the queen must return to the colony.

7. Onset of oviposition by naturally mated queens has a lognormal distribution. Due to the skewed distribution, the presentation of the results by the mean is misleading. The results should be presented by the median or the mode values.

8. It is not the queen, but that drone which fails to remove the mating sign of the predecessor, which determines the age at which the queen starts oviposition.

9. This paper presents a supplement to the book of Koeniger et al. (2014), which enriches the current knowledge of the mating biology of honey bees.

\section{REFERENCES}

Alber, M., Jordan, R., Ruttner, F., \& Ruttner, H. (1955). Von der Paarung der Honigbiene. Zeitschrift für Bienenforschung, 3, 1-28.

Franck, P., Solignac, M., Vautrin, D., Cornuet, J. M., Koeniger, G., Koeniger, N. (2002). Sperm competition and last-male precedence in the honeybee. Animal Behaviour, 64, 503-509.

Gorshkov, V., Blenau, W., Koeniger, G., Römpp, A., Vilcinskas, A., Spengler, B. (2015). Protein and peptide composition of male accessory glands of Apis mellifera drones investigated by mass spectrometry. PLoS ONE 195): e0125068. D0l:10.1371/journal. pone.0125068

Herrmann, H. (1969). Die Neurohormonal Kontrolle der Parrungsfluge und der Eilegetätigkeit bei der Bienenkönigin. Zeitschrift für Bienenforschung, 9, 09-544.

Koeniger, G. (no date). Paarung einer Bienenkönigin (Poster). Delta-Verlag, St. Augustin, Germany.

Koeniger, G. (1984) Funktionmorphologische Befunde bei der Kopulation der Honigbiene (Apis mellifera L.). Apidologie 15, 189-202.

Koeniger, N., \& Koeniger, G (2007). Mating flight duration of Apis mellifera queens: As short as possible, as long as necessary. Apidologie, 38, 606-611.

Koeniger, G., Koeniger, N., Elis, J., \& Connor, L. (2014). Mating biology of honey bees (Apis mellifera). Wicwas Press, LLC, Kalamazoo, Michigen, USA. 155 pp. http://jerzy_woyke.users.sggw.pl/2014_koeniger_ mating.pdf

Moritz, R., F., A. (1986). Intracolonial worker relationship and sperm competition in the honeybee (Apis mellifera L.). Experientia, 42, 445-448.

Roberts, W. C. (1944). Multiple mating of queen bees proved by progeny and flights test. Gleanings in Bee culture, 72, 255-259, 303. 


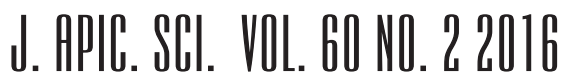

Schlüns, H., Moritz, R. F. A., Neumann, P., Kryger, P., Koeniger, G. (2005). Multiple nuptial flights, sperm transfer and the evolution of extreme polyandry in honeybee queens. Animal Behavior, 70, 125-131.

Taber, S. III (1954). The frequency of multiple mating honey bees. Journal of Economic Entomology, 47, 995-998.

Taber, S. III., \& Wendel, J. Jr. (1958). Concerning the number of times queen bees mate. Journal of Economic Entomology, 51, 786-789.

Tarpy, D. R., \& Page jr R. E (2000). No behavioral control over mating frequency in queen honey bees (Apis mellifera L.): Implications for the evolution of extreme polyandry. The American Naturalist, 15, 820- 827.

Triasko, V. V. (1951). Priznaki osemiennosti pchelinich matok. [Signs indicating the mating of queens]. Pchelovodstvo, 28(11): 25.

Woyke, J. (1955). Multiple mating of the honeybee queen (Apis mellifica L.) in one nuptial flight. Bulletin de L'Academie Polonaise des Sciences, Cl. II, 3(5), 175-180. http://jerzy_woyke.users.sggw.pl/1955_ multmat.pdf

Woyke, J. (1956). Anatomo-physiological changes in queen-bees returning from mating flights, and the process of multiple mating. Bulletin de L'Academie Polonaise des Sciences, Cl. II,4(3), 81-87. http://jerzy_woyke.users.sggw.pl/1956_anphymat.pdf

Woyke, J. (1958a). Przebieg kopulacji u pszczół. Pszczelnicze Zeszyty Naukowe, 2, 1-42. Polish, English Summary only, whole paper: http://jerzy_woyke.users.sggw.pl/1958_natural_unas.pdf

Woyke, J. (1958b). Histologiczna budowa organów rozrodczych trutnia. Poznańskie Towarzystwo Przyjaciół Nauk, Wydział Matematyczno-Przyrodniczy, Prace Komisji Biologicznej 19(2), 1-5. http:// jerzy_woyke.users.sggw.pl/histdron.pdf.

Woyke, J. (1960). Naturalne i sztuczne unasienianie matek pszczelich. Pszczelnicze Zeszyty Naukowe, 4,
183-275

http://jerzy_woyke.users.sggw.pl/1960_natur_szt_ unas_183_275_med.pdf (long time of opening)

Woyke, J. (1962). Natural and artificial insemination of queen honeybees. Bee World, 43, 21-25. http:// jerzy_woyke.users.sggw.pl/1962_nat_art_ins_ bw.pdf

Woyke, J. (1963). Contribution of successive drones to the insemination of a queen. XIX ${ }^{\text {th }}$ International Beekeeping Congress, Prague, Scientific Congress at Liblice 7-11 August 1963, Proceedings, Compete Texts of Lectures of XIX Congress of Apimondia: 715-718 http://jerzy_woyke.users.sggw.pl/contrsuccdr.pdf

Woyke, J. (1964). Causes of repeated mating flights by queen honeybees. Journal of Apicultural Research, 3, 17-23.

http://jerzy_woyke.users.sggw.pl/causesmat1964. pdf

Woyke, J. (2008). Why the eversion of the endophallus of honey bee drone stops at the partly everted stage and significance of this. Apidologie, 39, 627-636. http://jerzy_woyke.users.sggw.pl/2008_ evers_endophallus.pdf

Woyke, J. ( 2010). Three substances ejected by Apis mellifera drones during endophallus eversion as well as during natural matings with queen bees. Apidologie, 47, 613-621. http://jerzy_woyke.users.sggw. pl/2010_three_substances.pdf

Woyke, . (2011). Mating sign of queen bee originates from two drones and the process of multiple mating in honey bees. Journal of Apicultural Research, 50, 272-283. http://jerzy_woyke.users.sggw.pl/2011_ msign_2drones.pdf

Woyke, J., Jasiński, Z,, Prabucki, J., Wilde, J., Chuda-Mickiewicz, B., Siuda, M. ... Jojczyk, A. (2008). Onset of oviposition by honey bee queens, mated either naturally or by various instrumental insemination methods, fits a lognormal distribution. Journal of Apicultural Research and Bee World, 471), 1-9. http://jerzy_ woyke.users.sggw.pl/2008_onset_oviposition.pdf 
Woyke, J., \& Ruttner, F. (1958). An anatomical study of the mating process in the honeybee. Bee World, 39, 3-18. http://jerzy_woyke.users.sggw.pl/1958_ anatstud.pdf

Zander, E. (1921). Das Leben der Biene, Eugen Ulmer, Stuttgart pp. 195. 